\title{
Chapter 20 \\ Sociometry, Psychodrama, \\ and Experiential Teaching in Social \\ Work Education and Supervision
}

\begin{abstract}
This chapter is devoted to the use of Moreno's methods within education and supervision contexts to prepare the next generation of competent social work practitioners. The history and current state of Moreno's methods in US and international academia is outlined, along with limitations to embedding psychodrama within university settings. Social work education's history of experiential education is described with its relevance to sociometry and psychodrama as experiential teaching tools. Research on the effectiveness of experiential teaching and role-play in the classroom is offered and the importance of supervision in social work and psychodrama is highlighted. Examples and structured prompts are provided with a focus on using experiential sociometry processes (spectrograms, locograms, floor checks, step-in sociometry, hands-on-shoulder sociograms, and the circle of strengths) to enhance the learning experience of social work students, interns, and supervisees in various settings. Vignettes are also included which depict the use of written sociometric processes and psychodramatic role-plays within supervision or mentorship contexts.
\end{abstract}

Keywords Social work education $\cdot$ Social work supervision $\cdot$ Experiential teaching $\cdot$ Experiential education $\cdot$ Teaching psychodrama

The use of Moreno's methods in education and supervision offers facilitators opportunities to contribute in unique ways to the emergence of the next generation of social workers. Little has been written about the use of Moreno's methods in social work education or supervision as either content or process. This chapter will introduce the state of psychodrama in academia while focusing primarily on the use of sociometry, psychodrama, and sociodrama as teaching and supervisory processes within social work education and supervision. The text below includes examples of using Moreno's methods with social workers in educational contexts and supervision groups. The application of Moreno's experiential methods within various social work contexts offers engaging opportunities to nurture the next generation of social workers.

S. Giacomucci, Social Work, Sociometry, and Psychodrama, Psychodrama in Counselling, 


\subsection{Moreno's Methods in US and International Academic Contexts}

J. L. Moreno introduced psychodrama courses into the US higher education system beginning in 1937 at Columbia University and the New School for Social Research (Moreno, 1955). He later became an adjunct professor in the department of sociology at NYU from 1952 to 1966 (Marineau, 2014). "It was in the year 1923 when I set forth the dictum: "Spontaneity training is to be the main subject in the school of the future" (1946, p. 130). Moreno even proposed a "Spontaneity Theory of Learning" in the 1949 book titled Psychodrama and Sociodrama in American Education. His learning theory challenged the education focus on content learning by proposing "act learning." He writes that we learn developmentally through spontaneous action, and that we should train students to act with spontaneity and creativity (responding adequately/creatively) rather than to memorize content or mimic role behaviors (1949). These ideas are also reflected in Paulo Freire's 1974 Education for Critical Consciousness - "Acquiring literacy does not involve memorizing sentences, words, or syllables-lifeless objects unconnected to an existential universe-but rather an attitude of creation and re-creation, a self-transformation producing a stance of intervention in one's context" (2013, p. 45). Just as Moreno's theory of group psychotherapy elevated patients to the status of therapeutic agent, his theory of education elevates students to the role of learner-teacher (Giacomucci, 2019b).

At the time of this writing, this author was unable to locate a single active psychodrama degree program or concentration in the USA. Zerka Moreno's (2012b, p. 5) statement in the Psychodrama Network News rings true today: "there are master's tracks in a number of universities abroad. Why not in our country?" While sociometry, psychodrama, and experiential group therapies have very limited influence within academia in the USA, they are widespread in international institutes of higher education (Propper, 2003). There are multiple graduate degree programs around the world that not only include an elective on sociometry, psychodrama, and group psychotherapy_but award an entire master's degree in it. Nevertheless, there are a handful of graduate programs (psychology, counseling, education, or drama therapy) that offer an elective course on psychodrama, including Bryn Mawr College, Yeshiva University, West Chester University, Lesley University, New York University, Lewis and Clark College, Russell Sage College, Kansas State University, Antioch University, California Institute for Integral Studies (CIIS), among others. Though psychodrama is rarely taught in US universities, it is noted by Blatner and Blatner (1997), that "a derivative of Moreno's psychodrama, role-playing is widely used in education from preschool to professional graduate programs" (p. 124).

In an attempt to promote the integration of psychodrama into university programs, this author published a call to action in the Fall 2019 issue of the ASGPP Psychodrama Newsletter that advocated for increasing psychodrama's presence in academia while listing some of the reasons for the absence of Moreno's methods in academia as being related to the emergence of evidence-based practice, psychodrama's limited research base, the decline in group work education in degree programs, individualism, 
the dominance of the medical model, and a demonstrated lack of professionalism from psychodrama trainers beginning with Moreno himself (Giacomucci, 2019a).

\subsubsection{Psychodrama and Drama Therapy in Academia}

Although psychodrama has been unsuccessful thus far in securely establishing itself within US academic institutions, there are currently five accredited drama therapy programs in North America-all with licensure paths in their respective states. These include New York University, Lesley University, Concordia University (Canada), Antioch University, and California Institute of Integral Studies (CIIS). Many drama therapists refer to J. L. Moreno as "the first drama therapist" due to his use of the theater as a therapeutic modality (Brooke, 2006, p. 218). Johnson and Emunah's historical presentation of drama therapy suggests that the field emerged to fill the gap left by psychodrama's movement away from theater, toward clinical mental health practice (2009). The process of founding the North American Drama Therapy Association (NADTA) in 1979 included multiple psychodramatists, among others from education, psychology, and theater. Within two years of its foundation, there were two established drama therapy master's programs - one in California and one in New York. Johnson and Emunah comment that "the future of the field was dependent upon these two programs, and others to be established" (2009, p. 9).

Landy (2017) highlights that while psychodrama developed from Moreno's critique of psychoanalysis and traditional theater, drama therapy recognizes psychoanalysis and traditional theater as two of its major roots. Moreno may have marginalized his method by challenging the already established fields of theater and psychoanalysis which had been accepted within academia (Gershoni, 2009; Moreno, 2011, 2012a; Nicholas, 2017). This may be a significant lesson available to psychodramatists in the history of drama therapy's path toward recognition as a profession and establishment in university settings.

\subsubsection{Limitations to Psychodrama in the Classroom}

There are, of course, limitations to teaching psychodrama in the context of a university classroom setting (Giacomucci, 2019b). A major limitation to providing psychodrama in the classroom is that there are only about 200 certified Trainer, Educator, Practitioners (TEP)s through the American Board of Examiners and less than 400 certified practitioners (including the TEPs) in the USA. Considering the limited number of certified psychodramatists, it may be difficult for universities to find professors knowledgeable and experienced enough to teach a full psychodrama course.

The nature of psychodrama training is that it is almost entirely experiential; it is taught and learned in action. This emphasis on experiential learning defies the 
cultural conserve in US education, though some programs are increasingly utilizing experiential learning. Psychodrama is a powerful tool, which can create opportunity for incredible healing but also has a potential to harm. Adequate training in psychodrama requires experience working at levels of emotional depth that could be uncomfortable to many academics and students in a university setting, while also placing higher emotional demands on students than their other courses. Furthermore, asking students to access these depths of vulnerability in a classroom is nontraditional and may impact their ability to be present in other classes throughout the day. These limitations suggest that a course teaching sociometry and psychodrama would be insufficient in itself in terms of preparing students to competently practice psychodrama.

The balance between left-brain cognitive learning and right-brain emotional learning requires delicacy and containment in both teaching preparation and implementation. This dual focus challenges students to bring both their professional selves and their personal selves to the classroom. This experience can be utilized by the professor as an opportunity to teach appropriate boundaries and personal disclosures for social workers. It is important that the class session not become a therapy group, but that the focus remains on teaching. One creative way of maneuvering this process might be to orient the experiential processes toward emotional work needed to become a competent social worker. A common theme in most social work courses is students' insecurities when sharing about their field placement. A psychodrama course could provide students with an opportunity to work out their field placement insecurities through psychodrama while also learning the psychodramatic process.

A best practices document for teaching psychodrama in academic contexts has been developed by this author and ASGPP's Professional Liaison Committee which outlines the further limitations and recommendations for adapting psychodrama for university settings (Giacomucci, 2020b). A psychodrama course can provide students with a comprehensive theoretical understanding of J. L. Moreno's philosophical system, an experiential understanding of sociometry, an introduction to psychodramatic techniques, and training in experiential group therapy. After completion of a course, students would be able to competently use multiple pen-to-paper and experiential sociometric tools, psychodramatic techniques, multiple experiential sociometry processes, and a variety of group warm-up exercises. Nevertheless, after completing a single semester course, students would not be prepared to direct a full psychodrama.

The ABE psychodrama certification process of $780 \mathrm{~h}$ is more classroom hours than the entirety of most graduate degrees. The completion of a course or program concentration in psychodrama would propel a student toward ABE certification in that they had obtained a wealth of hours in their educational program (for more info, visit www.psychodramacertification.org). The $45 \mathrm{~h}$ of classroom instruction from a 3 credit course could be credited toward the $90 \mathrm{~h}$ required for certification as an experiential therapist (CET) through the International Society of Experiential Professionals (ISEP), which puts students halfway to certification (for more info, visit www.ExperientialProfessionals.com). 


\subsection{Experiential Teaching, Moreno's Methods, and Social Work Education}

J. L. Moreno states that in discerning between immigrating from Vienna to either the USA or Russia, he chose "the land of Dewey" and was attracted to Dewey's theory of constructivism- "knowing by doing" (Oudijk, 2007) and advocating for reforms in the educational system (Drakulić, 2014). John Dewey, regarded by many as the father of experiential education, in 1916 states, "give the pupils something to do, not something to learn; and the doing is of such a nature as to demand thinking; learning naturally results" (p. 191). Psychodrama offers a potent form of experiential learning that has been used in social work education only minimally. As early as 1944, a social worker, Mary Bosworth Treudley, had advocated for the use of psychodramatic roleplays in social work education and supervision to create opportunities for students to directly observe case scenarios. Around the same time, St. Elizabeths Hospital was using psychodrama to train social work, psychology, and nursing interns on communication skills with psychiatric patients (Buchanan \& Swink, 2017). The Journal of Teaching in Social Work offers numerous articles that demonstrate that the experiential teaching process has a positive effect on learning outcomes (Banach, Foden, \& Carter, 2018; Dalton \& Kuhn, 1998; Fleischer, 2018; Foels \& Bethel, 2018; Kaye \& Fortune, 2001; Kramer \& Wrenn, 1994; McKinney, O'Connor, \& Pruitt, 2018; Powell \& Causby, 1994; Quinn, Jacobsen, \& LaBarber, 1992; Whebi, 2011; Whiteman \& Nielson, 1990). While others have noted over the past 50 years that group work courses in social work education have gradually shifted away from strictly didactic teaching methods, toward experiential teaching (Euster, 1979; Gutman \& Shennar-Golan, 2012; Stozier, 1997; Warkentin, 2017; Zastrow, 2001).

Many social work educators argue that social work education should focus more on the process of teaching than the content of teaching (Fox, 2013; Gitterman, 2004; Kolb, 2014; Rogers, 1961; Schön, 1987; Shulman, 1987). In social work education, the curriculum content traditionally has been overemphasized with much less attention given to the process of how students learn (Gitterman, 2004). In a practice profession such as social work, "the process of teaching and the content of the subject matter should go hand in hand" (Fox, 2013, p. xi). Kolb, a strong advocate of experiential learning, states that "the experiential learning model pursues a framework for examining and strengthening the critical linkages among education, work, and personal development" (1984, p. 4). While Keeton and Tate emphasize experiential learning in that:

...the learning is directly in touch with the realities being studied.... It involves direct encounter with the phenomenon being studied rather than merely thinking about the encounter or only considering the possibility of doing something with it. (1978, p. 2)

Rogers (1961) highlights two types of learning - cognitive learning and experiential learning. He advocates for experiential learning by highlighting how it is more meaningful and relevant to the learner because it completely involves the student and integrates the instructional process with the course objectives. The experiential 
learning process includes the cycle of moving an abstract concept to concrete experience, personal reflection, and student experimentation (Georgiou, Zahn, \& Meira, 2008; Koob \& Funk, 2002; McCarthy, 2010). Wehbi offers her reflections on the mechanisms of experiential teaching:

experiential teaching methods within the classroom may provide students with the opportunity to experience specific ways of being and doing, to model to one another skills and attitudes they could carry into practice, and to extend classroom activities outside the class setting. (Wehbi, 2011, p. 502)

Considering that the classroom is at its foundation a group (Shulman, 1987), and that the dynamics within the group experience are present and acted out (it would be impossible for it to be otherwise), it is fitting to teach group work in a group setting using experiential teaching (Fleischer, 2018). Kolb and Kolb highlight that "the magic of experiential learning lies in the unique relationship that is created between teacher, learner, and the subject matter under study" (2017, p. xxiv). The application of experiential teaching in the instruction of group work introduces students to the magic of these processes.

\subsubsection{Experiential Learning and Role-Play in the Classroom}

Research has demonstrated the efficacy of simulated sessions (Bogo, Rawlings, Katz, \& Logie, 2014; Lu et al., 2011; Mooradian, 2007, 2008; Rawlings, 2012) and role-plays (Macgowan \& Vakharia, 2012; McGovern \& Harmsworth, 2010; Shera, Muskat, Delay, Quinn, \& Tufford, 2013) for clinical skills training. Williams (1995) highlights that educational simulations often are designed by the facilitator to arrive at an already known learning objective while psychodramatic or sociodramatic role-plays are spontaneous enactments. Experiential learning is widely regarded as effective for teaching students in multiculturalism courses (Arthur \& Achenbach, 2002) and for increasing competencies around diversity and working with oppressed groups (Schreiber \& Minarik, 2018). Additionally, many studies have demonstrated that experiential learning is essential for students to translate theory into practice and understand group dynamics (Furman et al., 2009; Ieva et al., 2009; Macgowan \& Vakharia, 2012; Swiller, 2011; Yalom \& Leszcz, 2005).

A 1994 meta-analysis on the retention of knowledge demonstrated no difference in student's forgetfulness of the content, except in comparison to experiential teaching (Semb \& Ellis, 1994). Specht and Sandlin's (1991) comparison study on the retention of course content between learning by lecture versus experiential role-plays had similar findings. At the six week follow-up, students who learned the content through lecture were showing a decline in problem solving by $54 \%$ and an $18 \%$ drop in concept recognition while the students who learned through experiential role-plays showed only a $13 \%$ drop in problem solving and did not demonstrate any decline in concept recognition (Specht \& Sandlin, 1991). 
Through the use of role-play in the classroom, the learning experience moves beyond a cognitive exercise to include skill development (Carey, 2016; Konopik \& Cheung, 2013; Warkentin, 2017). This offers the student "an integrative approach to learning that balances feeling, thinking, acting and reflecting" (Kolb \& Kolb, 2005, p. 200). Dennison (2005), Macgowan \& Vakharia (2012), and Shera et al. (2013) found that students' participation in role-plays in the classroom contributed more than anything else to their development of knowledge and skill in group work. Warkentin describes the use of using role-playing to simulate a treatment group in the social group work classroom, indicating it as "one of the more significant learning activities for students" (2017, p. 237). The role-play is teaching technique that can be adapted for use with nearly any topic, skills training, or profession. Providing educators with a basic understanding of Moreno's phases of an enactment (warm-up, enactment, sharing) would greatly increase the efficacy of role-plays in the classroom. It is arguable that most role-plays in the classroom do not bear fruit because there was not an adequate warm-up to the enactment.

A Brazilian author proposes the use of "educational psychodrama" and highlights is frequent use in Brazil for training medical students through role-playing techniques (Gomes et al. 2006; Liberali \& Grosseman, 2015). A team of Spanish researchers positively assessed educational psychodrama as a teaching strategy in university settings (Maya \& Maraver, 2020). Sociodrama and psychodrama have been used in higher education to teach social educators (Haas, 1949; Jacobs, 1950; ter Avest, 2017; Veiga, Bertao, \& Franco, 2015), lawyers (Cole, 2001), business professionals (BidartNovaes, Brunstein, Gil, \& Drummond, 2014; Wiener, 1988), medical professionals (Baile \& Blatner, 2014; Moreno \& Moreno, 1959; Walters \& Baile, 2014), nurses (McLaughlin, Freed, \& Tadych, 2006; Moreno \& Moreno, 1959), and other students (Blatner, 2006; Blatner \& Blatner, 1997; Haworth \& Vasiljevic, 2012; Michaels \& Hatcher, 1972).

In a Sect. 15.1, I suggested sociodrama to be superior to psychodrama as a teaching method in classroom settings. Sternberg and Garcia even describe sociodrama as "a kinesthetic, intuitive, affective, and cognitive educational technique" (2000, p. 4). Brazilian authors Nery and Gisler (2019) describe sociodrama as an experiential education method par excellence. Role-playing can also be useful in the classroom to develop a richer understanding of various content including history, myth, religion, or literature (Haworth \& Vasiljevic, 2012; Nolte, 2018). Others have highlighted sociodrama's utility as a therapeutic approach in high school settings (Landis, 2020). Propper (2003) describes using an empty chair process to provide students with an opportunity to psychodramatically encounter figures from history, myth, literature, and religion. This could give new social work students not just an intellectual relationship to major figures in social work history, but also an emotional connection. Imagine first year MSW students engaging in a psychodramatic dialogue with Jane Addams, Mary Richmond, Sigmund Freud, or even Jacob Moreno! Nolte (2018) describes using role-playing in the classroom as follows:

It is one thing to read about a character's thoughts, words, and actions in a novel; it is different to enact and experience being that character in that character's situation through role-playing. Answering questions from classmates and justifying the character's actions 
deepens the experience. Action learning is more natural, and more like everyday learning from life events, than traditional methods. It is more interesting than being talked to or engaging in questions and answers. Role-playing results in a more integrated, experienced, felt understanding of the material. (p. 192)

Beyond teaching sociometry as content, the utilization of sociometry in the education process offers educators meaningful opportunities to enhance the learning environment. Much has also been written about the utility of sociometry within the classroom as a tool for psychosocial safety, group cohesion, learning needs assessment, assessment of preference, and training in interpersonal relations (Evans, 1962; Giacomucci, 2018, 2019b; Giacomucci \& Skolnik, in-press; Guldner \& Stone-Winestock, 1995; Haas, 1949; Haworth \& Vasiljevic, 2012; Propper, 2003). Guldner and StoneWinestock articulate that "the sociometric connections between people, the sociometric structure of groups, and the sociometric status of individuals are significantly related to learning" (1995, p. 184). An instructor with a basic understanding of sociometry can create an educational environment more conducive to learning by conceptualizing learning as a social function (Cozolino, 2014; Jones, 1968; Siegel, 2012).

\subsection{Moreno's Methods in Social Work Supervision}

The centrality of supervision within the social work field has been established since the early years of the profession and has been formalized through multiple avenues including: CSWE standards for accreditation related to field placement supervision, agency policies, and license requirements (Kadushin \& Harkness, 2014; Shulman, 2010b). Supervision in clinical social work has multiple functions including mentoring, education, oversight, management, preventing negative outcomes, and improving positive outcomes (Kadushin \& Karness, 2014; Mor Barak et al., 2009; Munson, 2012; Shulman, 2010b). Social work supervision, like the social work profession, emphasizes the importance and centrality of relationships. Parallels between the social worker-client relationship and the supervisor-supervisee relationship are often highlighted. In social work supervision, the relationship between supervisor and supervisee is the vehicle for change (Shulman, 2010b). While supervision is a core component of the social work field, the prospect of using psychodrama for clinical social work supervision has been underutilized and rarely written about (Ramsauer, 2007).

Pugh remarks that "a central element to social work education is experiential learning, most exemplified in the signature pedagogy of the field placement" (2014, pp. 17-18; Kolb, 2014; Raschick, Maypole, \& Day, 1998; Sachdev, 1997). From the perspective of a role theory, the supervised student's field placement is a roleplay. The MSW student is receiving supervision, education, and training to competently hold the role of social worker (medical, clinical, community, drug \& alcohol, etc.). The role training begins through dynamic doubling and mirroring between student, educator, and supervisor until the student begins to develop competencies 
and confidence in the role. At this point, they have shifted from the role training into role-playing phase of role-development.

Cheung, Alzate, and Nguyen (2012) offer a case study highlighting the role training of an MSW student completing a psychodrama internship resulting in an increase in student confidence and clinical skills. According to a study by Yalom and his colleagues, therapists facilitating group therapy without supervision and training were actually found to be less skilled at a six month assessment—presumably because "original errors may be reinforced by simple repetition" (Ebersole, Leiderman, \& Yalom, 1969; Yalom \& Leszcz, 2005, p. 549).

The 1969 CSWE curriculum change toward a more generalist practice approach significantly impacted the number of group work courses and concentrations for the previous generation of social work students, who are now the current generation of clinical social work educators, field instructors, and field placement supervisors (Carey, 2016). Lack of qualified social work field placement supervisors who have group work training is a serious concern (Carey, 2016; Goodman \& Munoz, 2004; Knight, 2017; LaRocque, 2017; Tully, 2015). How can field instructors without group therapy training provide students with group therapy training? Furthermore, the number of clinical social workers and field educators with psychodrama training is significantly lower. In 2011, $11 \%$ of ABE certified psychodramatists held social work credentials (ABESPGP, 2011, as cited in Konopik \& Cheung, 2013). As of 2020, the American Board of Examiners in Sociometry, Psychodrama, and Group Psychotherapy website includes 113 certified practitioners who also have social work degrees which is just under $30 \%$ of all ABE certified psychodramatists. This is a significant increase in social workers obtaining psychodrama certification in the past decade. The Bureau of Labor Statistic's estimates that in 2016, there were a total of 682,100 social workers in the USA (BLS, 2018). Considering these figures, the percentage of social workers that are also ABE psychodrama certified is as low as $0.017 \%$. The richness of sociometry and psychodrama has only been utilized minimally by social workers, nevertheless it offers powerful group tools for social work facilitators.

When discussing the role of supervisor, is also helpful to consider the sub-roles within the role of supervisor. Using role theory to dissect the functions of the supervisor role is congruent with psychodrama's role theory and parallels Kellermann's model of the roles of psychodrama director (1992). Various conceptualizations of the sub-roles of supervisor exist in the literature (Bernard, 1979; Center for Substance Abuse Treatment, 2009; Daniel, 2012; Hawkins \& Shohet, 2012; Williams, 1995); however, this writer finds the following to be simplest:

Educator-addresses learning needs of supervisee, identifies clinical competencies while offering suggestions for increasing effectiveness, provides resources, and focuses on skills training and continuing education.

Supporter-provides validation, inspiration, and offers emotional support to the supervisee related to job stress, countertransference, self-exploration, and personal issues as they impact professional work. 


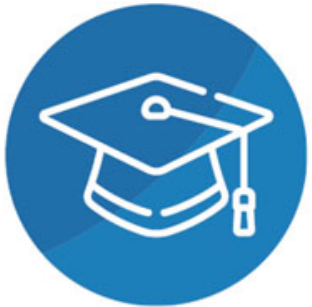

Educator

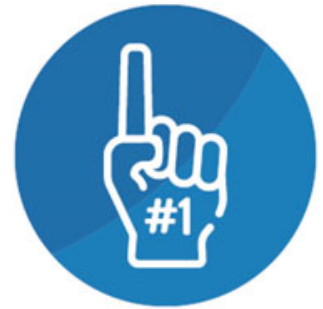

Supporter

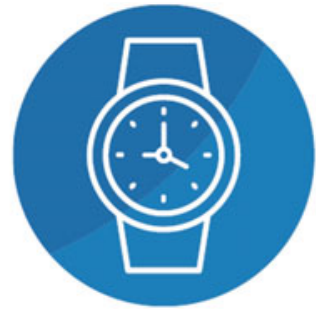

Manager

Fig. 20.1 Three roles of supervisor

Manager-assesses supervisee's performance, productivity, and functioning within code of ethics and organizational policies while supporting proper completion of documentation and professional responsibilities.

A competent supervisor integrates these three sub-roles (see Fig. 20.1) into their relationship with supervisees, effectively providing interpersonal support, education for increased competencies, and logistical management to help supervisees operate within organizational systems and professional code of ethics. This conceptualization of the sub-roles of supervisor can be useful for the training of new supervisors and assessing the balance of the supervisory relationship.

\subsubsection{Importance of Psychodrama Supervision}

One of the primary purposes of supervision could be described as helping the supervisee develop new response to old situations and adequate responses to novel situations in their work (Chesner, 2008). This is precisely Moreno's definition of spontaneity - which highlights the philosophical importance of spontaneity and supervision in psychodrama. The emphasis on spontaneity in psychodrama supervision is useful for helping supervisees get unstuck and develop new creative ways of working with their clients. The centrality of supervision in psychodrama is also evidenced in the stringent supervision requirements in both the psychodrama practitioner and trainer certifications in the USA and internationally (Krall, Fürst, \& Fontaine, 2012). Psychodrama's practitioner certification $(\mathrm{CP})$ requires at least a year-long supervised practicum while the trainer credential (TEP) requires a minimum of three years of supervised training while receiving regular supervision. As noted at various points in this book, psychodrama is a powerful tool that can create much harm when used inappropriately - because of this, supervision is especially important for competent and ethical practice.

Though supervision is a core component of the psychodrama training process, little has been written about it and almost no research is available on it (Krall, 2012; Tabib, 2017). Daniel (2012) notes that psychodrama training is focused on content, 
theory, philosophy, concepts, and techniques, while psychodrama supervision is more oriented on developing professional identity and competence in practice. Dudler and Weiß (2012) highlight the essential role of psychodrama supervision in helping the psychodramatist integrate their new professional identity while also adapting their psychodrama learning to fit their unique practice environment. Many have suggested that skills and knowledge related to clinical work are also applicable skills and knowledge for the supervisor's practice-especially emphasis on the relationship (in this case between supervisee and supervisor) and attention to the phases of a session (Krall \& Fürst, 2012).

Though traditional case presentations in supervision are done verbally, psychodrama allows for the case presentation process to become experiential through role-playing. Using psychodramatic role-playing or sculpting to re-enact supervisee's experiences with clients creates "an environment similar to the one-way mirror setting, except we are in the room with the supervisee-observing, interacting, and co-creating" (Ochs \& Webster, 2017, p. 112). Psychodrama role-plays in supervision allow for the exploration of a supervisee-client relationship embodied in action rather than through the recounting of memories from the supervisee (Ochs $\&$ Webster, 2017). In this process of re-enacting the supervisee's experience with their client, there are opportunities for reflection, processing, and experiential practice of new interventions (Apter, 2012). In psychodrama supervision, the process and content of supervision are integrated (Tabib, 2017). In a similar way, psychodrama processes can be used within the social work supervision context (Ochs, 2020). Furthermore, Gimenez Hinkle (2008) and Williams (1988, 1995) highlight the utility of using psychodrama in supervision to work through parallel processes and countertransference issues which will be depicted in a later vignette (see Sect. 20.5).

\subsubsection{Written Sociometric and Psychodramatic Tools in Individual Social Work Supervision}

The quality of individual social work supervision can be enhanced with an integration of simple written sociometric and psychodramatic tools that promote self-reflection, future goal setting, and action insight. Some of these written tools include the role atom, social atom, sociogram, psychodramatic timelines, psychodramatic journaling, and psychodramatic letter writing-for an in-depth presentation of these tools, see Chap. 16. While these instruments are primarily used with clients in clinical settings, they can also be modified to explore the professional self and professional development. For example, the social atom could be used as a relational assessment to depict the nature of a supervisee's professional relationships. Or a supervisee could use a sociogram to depict their perception of the sociodynamics within their agency team including coworkers, managers, and leadership. A timeline can be useful in assisting a supervisee in appreciating the development of their professional self or career. This writer has found timelines to be useful with retiring professionals to celebrate 
their achievements and with new professionals to create a future projection of where they what they would like their career to look like. Psychodramatic journaling and letter writing are useful as an adjunct to the timeline as they facilitate a supervisee role reversing with their past or future professional selves along their timeline of professional development. Psychodramatic journaling and letter writing can also be useful for working their emotional blocks related to professional life or exploring new professional possibilities. Perhaps the role atom is one of the most useful written Morenean tools for professional development as it orients itself as an assessment of the self-in this case, the professional self. This writer has developed a practice of using the role atom as a future visioning tool for navigating the time and space each professional role encompasses within my professional identity (see Fig. 20.2). I strive to annually draw my current professional role atom and my ideal professional role atom one year in the future which helps me to concretize and visualize which professional roles I want to increase or decrease going forward. This book is a manifestation of the effects of annually drawing my professional role atom as it helped me articulate and commit to reducing my clinical and administrative professional roles to make space for the writer role.

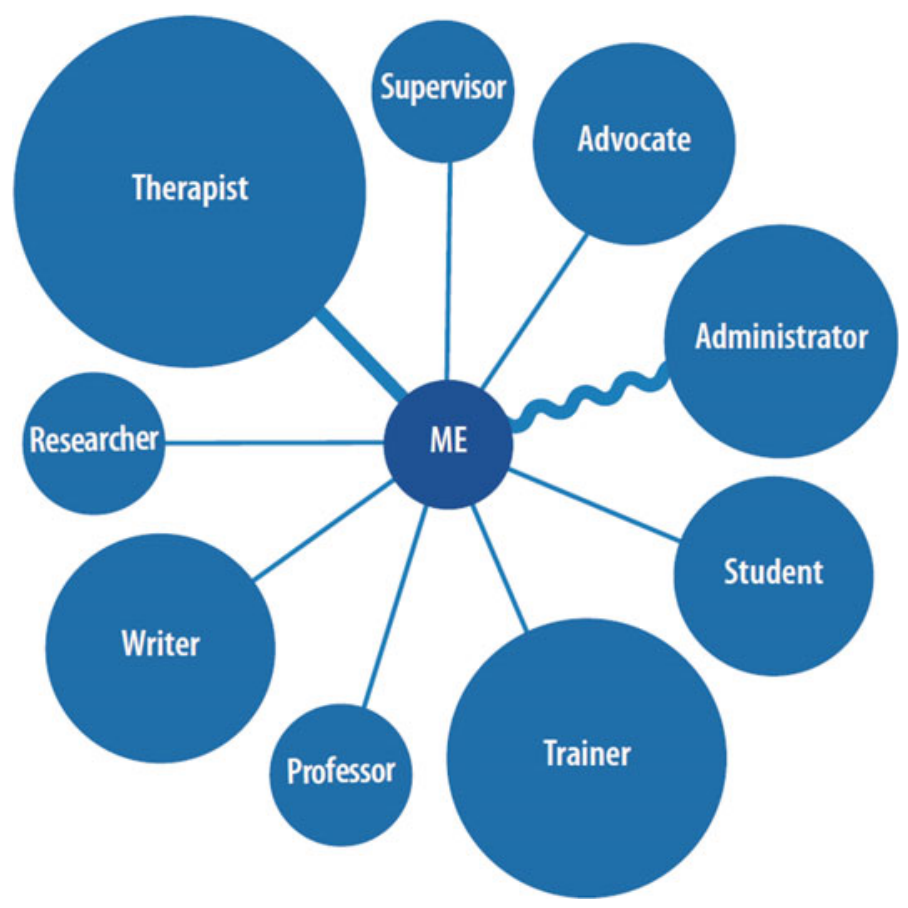

Fig. 20.2 Professional role atom 


\subsection{Experiential Sociometry in Social Work Education and Supervision Groups}

Any content from social work courses can be presented to students or groups of supervisees through experiential teaching methods that utilize sociometry and/or role-playing techniques. Moreno's methods allow a social work educator or supervisor to bring the mentoring experience to life and move from lecture or discussion into action. Below are some simple examples of sociometry tools that can be implemented for various social work teaching structures for classroom sessions, post-graduate trainings, or supervision groups. Similar to clinical (see Chap. 11) and community sociometry prompts (see Chap. 18), it is helpful to use the three phase clinical map to discern the order of prompts in a way that warms up the group and keeps the process safe.

\subsubsection{Spectrograms}

As outlined in previously (see Sect. 11.3 for more detail and a video link), the spectrogram is a group-as-a-whole assessment that provides a facilitator with a quick and efficient assessment of the group's experience or understanding of a specific topic (Giacomucci, Gera, Briggs, \& Bass, 2018). Using the room as a sliding scale from 0 to 10 , participants are asked to physically place themselves on the spectrum based on their self-assessment of the prompt. Each spectrogram prompt provides opportunities for students to self-reflect, see where they fit within the group, and to access mutual aid by sharing with each other (Giacomucci, 2020a). As depicted in the examples below, spectrograms can be useful for social work educators and supervisors to explore students' relationships to the course content and their experience of the learning process.

\section{Topic: Social Policy}

1. How interested are you in social policy?

2. How much experience do you have in policy work?

3. How applicable is your learning of social policy to your current field placement?

4. How much do your agency policies effect your clients?

\section{Topic: Research Methods}

1. How much research experience do you have?

2. How motivated are you to learn research methods?

a. How interested are you in quantitative methods?

b. How interested are you in qualitative methods?

3. How competent do you feel interpreting the results of research studies? 
4. How important do you think research is for the social work field?

\section{Topic: Social Work with Groups}

1. How much experience do you have participating in groups of any kind?

2. How often are you expected to facilitate groups in your field placement?

3. How confident do you feel as a group facilitator?

\section{Topic: Social Justice}

1. How much experience do you have participating in social justice movements?

2. How often do your field placement client sessions involve discussions of social justice?

3. How well do you think your field placement site does in advocating for social justice?

4. How confident do you feel as an advocate for social justice?

The use of spectrograms in the classroom actively engages students to consider their relationship to the content while discussing their experiences and beliefs with their peers. In a traditional classroom, the level of participation often varies significantly from student to student with some students offering input regularly while others rarely speak. The spectrogram is a tool that creates an inclusive experience where everyone can participate and share in smaller groups or dyads. Spectrograms are also useful for evaluations mid-semester or at the end of the semester. They provide an action-based alternative to written evaluations. In supervision groups, the spectrogram can be a cultivating agent for mutual aid between supervisees.

\subsubsection{Floor Check}

The floor check (see Sect. 11.5 for more detail and a video link) allows students or supervisees to interface with a topic and subtopics through a reflective mutual aid process. A floor check is facilitated by simply printing out pieces of paper labeled with various subtopic criteria and offering a series of prompts where participants stand at the criteria that best answers the prompt from them. With each prompt, a new configuration of smaller groups emerges based on similar experience and participants share briefly with those standing with them about their choice (Giacomucci, 2020c). It is helpful to offer an option for "other" with most topics and to also maintain a 3-5 person ratio between the size of the group and the number of options offered. Below are a series of floor check examples for social work educational and supervisory settings.

Social Work Core Values Floor Check-integrity; competence; services; social justice; importance of relationships; dignity/worth of each person.

1. Which value do you feel most represents the social work field? 
2. Which value do you feel that you best embody in your work?

3. Which value do you feel your field placement agency best embodies?

4. Which value do you feel is most overlooked by social workers?

5. Which value would you like to more fully integrate into your work going forward?

Mental Health Diagnoses Floor Check-mood disorders (depression, bi-polar, etc.), anxiety disorders, personality disorders, substance abuse or eating disorders, dissociative disorders, psychotic disorders; other.

1. Which do you feel most comfortable working with?

2. Which do you feel is least understood in the field?

3. Which do you feel least competent to work with?

4. Which do you feel you have improved your knowledge of in the past year?

Social Work Practice Areas Floor Check-clinical social work; casework; social group work; macrosocial work; social work academia; other.

1. Which area do you feel most prepared to work in?

2. Which area do you feel most intimidated to work in?

3. Which area could contribute to improving the quality of your current field placement?

4. Which area have you become more interested in since starting your MSW program?

Social Work Practice Sites Floor Check-schools; prisons; treatment centers; universities; non-profit agencies; government agencies; hospitals; other.

1. Which practice site is your current field placement?

2. Which practice site do you have the most experience of in the past?

3. Which practice site do you think would be most difficult for you to work in?

4. Which practice site would you most want to work in?

The floor check process positions students or supervisees as mutual aid agents for each other as they share, support, and educate one another through throughout each floor check prompt. The floor check leverages relationships between participants to create a social learning experience while creating movement in the classroom. Each floor check prompt is inherently diagnostic as it reveals the preferences, experiences, or views of the group as they related to the content of the prompt. Having assessed a group of students with a floor check, the instructor can adapt the content of future sessions to follow the warm-up or meet the needs of students. 


\subsubsection{Step-In Sociometry}

Step-in sociometry (see Sect. 11.6 for more detail and a video link), or circle of similarities, is a useful group tool for highlighting similarities and shared experiences between participants (Giacomucci, 2017). It is particularly useful for beginning stages of groups as it helps to uncover similarities while normalizing difficult experiences. Participants begin in a standing circle and take turns making statements about themselves while physically stepping into the circle. When a statement is offered, other participants also step into the circle to indicate their sense of connection to the statement. The process can be facilitated without any verbal sharing which is more time efficient and sometimes feels safer for participants as they can self-disclose without talking about details. Or brief sharing can take place related to the various step-in statements. Below are some examples of using step-in sociometry with students or supervisees:

\section{Group: Inpatient Addictions Treatment Center Cohort of New Interns}

1. Step in and name something you like to do that is not related to your career

2. Step in and identify something that attracted you to this field placement

3. Step in and name something you find difficult as a student or intern

4. Step in and share a hope or goal for your future career.

\section{Group: Trauma-Informed Supervision Group}

1. Step in and name something you do to practice in a trauma-informed way

2. Step in and identify a trauma-related issue that your clients struggle with

3. Step in and share one way you would like to grow as a trauma-informed social worker.

\section{Group: MSW Students About to Graduate}

1. Step in and share one thing that has helped you throughout your MSW program

2. Step in and share one thing that you found difficult throughout your MSW program

3. Step in and share one way you intend to use your MSW degree going forward.

\section{Group: Social Work with Children Course}

1. Step in and state one reason why you are interested in working with children

2. Step in and share one thing related to work with children that you would like to learn.

\section{Group: Social Work License Exam Prep}

1. Step in and share one aspect of the license exam you feel confident about 
2. Step in and name one aspect of the exam you feel insecure about

3. Step in and share one way you plan to celebrate passing your exam.

Whether with social work supervisees or students, the step-in sociometry process reveals the invisible connections and similarities between participants which helps to increase group cohesion. Participants often come away from the exercise with an enhanced sense of universality and what Shulman (2010a) describes as the "all in the same boat" phenomenon.

\subsubsection{Hands-on-Shoulder Sociograms}

Another sociometry tool that offers utility for social work supervisors and educators is hands-on-shoulder sociograms. Much has been published about using sociograms in educational settings, especially with children and adolescents (Evans, 1962; FerráVindel \& Jimenez, 2011; Jennings, 1948; Sobieski \& Dell'Angelo, 2016). The sociogram reveals the underlying sociodynamics within the classroom or supervisory group. As outlined in previous chapters, the sociogram can be created through a pento-paper sociometric test or in action. Section 5.5 includes an example of a sociogram created within an MSW classroom using a sociometric test where students indicated their top three preferences for co-facilitators from the student group. The resulting sociogram was created using a computer program that efficiently generated the image while also making the data anonymous. An examination of the sociogram provides both students and the professor with an enhanced understanding of the distribution of choices within the group based on the criteria of the prompt. In this case, the sociometric test was used to teach sociograms while also choosing co-facilitators for a future assignment. Information from a sociogram can help participants and facilitators assess the social forces within the group, make group decisions based on the outcome, and intervene to develop a more inclusive group experience.

Sociograms can also be facilitated in action by providing a specific prompt and instructing participants to put their hand on the shoulder of the person who best answers the given criteria. The experiential sociogram, or hands-on-shoulder sociogram, allows participants to see in the here-and-now who is choosing them. Once participants have indicated their choice by putting their hand on the shoulder of one other group member, they can be invited to share briefly with that person their reasons for making their choice which can significantly enhance interpersonal relationships. In this process, it is important to obtain consent for physical touch and to be attentive to the possibility of specific students or supervisees being unchosen in multiple prompts. When this happens, the facilitator can create a new prompt with new criteria that makes the previously unchosen participants highly chosen. Handson-shoulder sociograms reveal to the group and individuals within it how individuals are experienced by other participants which can be useful information when making group decisions or warming-up to new collaborations. Below are some examples 
of hand-on-shoulder sociogram prompts in social work educational or supervisory settings:

\section{Group: MSW Class on Community Social Work}

1. Place your hand on the shoulder of someone who you feel has similar professional interests as you

2. Place your hand on the shoulder of someone who has said something that challenged you to look at an issue in a new way

3. Place your hand on the shoulder of someone who you would like to get to know better

4. Place your hand on the shoulder of someone who you could see yourself writing a paper with

5. Place your hand on the shoulder of someone who you would want to advocate on your behalf for something important to you.

\section{Group: Social Work Doctoral Students After Presenting Dissertation Proposals}

1. Place your hand on the shoulder of someone whose work relates to your own

2. Place your hand on the shoulder of someone whose dissertation topic is one that you do not know much about but would like to understand better

3. Place your hand on the shoulder of someone who you feel you could ask for support from if you felt stuck with your dissertation writing

4. Place your hand on the shoulder of someone who impressed you with their presentation skills.

\section{Group: Clinical Social Work Interns}

1. Place your hand on the shoulder of someone whose field placement site interests you

2. Place your hand on the shoulder of someone who has helped you understand your clients better

3. Place your hand on the shoulder of someone who you feel you could learn from to become a better social worker

4. Place your hand on the shoulder of someone who reminds you of one of your social work role models

5. Place your hand on the shoulder of someone whose work you would like to hear more about.

\subsubsection{Circle of Strengths}

The circle of strengths(see Sect. 11.8 for more detail and a video link) can also be adopted for supervisory and educational settings. This process uses concretization to 
externalize strengths of participants, the group-as-a-whole, or other entities (Giacomucci, 2020c). Generally, scarves are used as props to represent strengths, but any objects can be used instead. The circle of strengths can be useful in social work classrooms and supervision groups to help establish safety, connection, and cohesion between participants prior to emotionally charged or difficult discussions. The strengths-based process and attention to safety facilitate a more conductive learning environment for everyone involved. Here are a few different ways to modify prompts based on different settings or topics:

\section{Group: MSW Racism Class}

1. Choose a scarf to represent a strength that can help you have conversations about racism

2. Choose a scarf to represent a strength you see in your partner that can help them have discussions about racism

3. Choose a scarf to represent a strength you see in the social work field that can help combat racism.

\section{Group: Social Work Students at the Start of their Field Placement}

1. Choose a scarf to represent one of your strengths that can help you be successful at your field placement

2. Choose a scarf to represent a strength you see in your partner that can help them at their field placement

3. Choose a scarf to represent a strength you see in this group that can help support positive field placement experiences.

\section{Group: Social Work with Groups Course}

1. Choose a scarf to represent one of your strengths that can help you as a group facilitator

2. Choose a scarf to represent a strength you see in your partner that can help them as a group facilitator

3. Choose a scarf to represent a strength you experience as unique to the group work. approach

With each prompt, participants can identify their strengths and rational for their choice in front of the entire group, in smaller groups, or in dyads. After the strength has been concretized with a scarf or other object, it can be placed on the floor to create a large circle of strengths. The presence of the circle of strengths is a conscious reminder of each individual's strengths and the collective strength of the group which can help participants lean into difficult conversations later in the session. The process of creating the circle and identifying strengths, especially in others, cultivates an atmosphere of vulnerability, appreciation, and positive connection between participants which can serve as a holding environment for difficult emotions later in the session. 


\subsection{Role-Play in Social Work Education and Supervision}

The educational and supervisory process becomes moves beyond words and cognition through the use of experiential sociometry and role-play. The social work educational literature includes various examples of using role-play as an educational tool. Nevertheless, many students and professors are anxious about participating in or facilitating role-plays in the classroom. At this point, it is helpful to remember Moreno's hypothesis of the inverse correlation between anxiety and spontaneity (1953). If anxiety is high, the role-play will lack spontaneity. My own experience of social work educators using role-play is that they regularly neglect the warming-up process and instruct students to move directly into the enactment. It is this writer's belief that the failure of educational role-plays is largely related to the lack of attention given to the warm-up. The warming-up process will be different for each role-play, nevertheless, the sociometric processes described in Sect. 20.4 offer multiple experiential warm-ups for educators interested in improving the outcomes of role-plays in the classroom.

There are a plethora of ways that role-playing could be used in social work classrooms and supervisory settings. Chapter 19 depicts the use of role-playing in social work settings to role train responses to racism and microaggressions as well as teaching advocacy skills for social workers advocating to insurance companies, policy makers, and employers. A popular application is the use of role-playing in social work education is to re-enact students' interactions with clients from their field placement. This is a simple way to use the students' process recordings as a script allowing them to revisit clinical choices with the input of their peers and critically consider alternative interventions. The student can also be role reversed with their client to cultivate greater understanding and insight into their client's experience. This method removes much of the action demands on role players as they can rely on the process recording script for their role enactment. One way to enhance this process and infuse it with spontaneity would be to invite other students (and the professor/supervisor) to offer doubling statements or short role reversals that demonstrate different interventions or responses to the situation at hand. This method is particularly useful in supervision groups and offers an experience of mutual aid and role training for participants. This writer has employed the method at hand in a large supervision group for addictions counselors which included each therapist demonstrating their own unique way of responding to a difficult client situation. Throughout the process, participants were able to witness over 20 different styles of responding to the same situation which varied due to each individual therapists' personality, background, and clinical training.

Another useful implementation of role-playing in clinical social work settings is within license preparation courses or classes focused on assessment and diagnosis. Participants can be assigned, or sociometrically choose, a specific mental health diagnosis. Each participant reviews the diagnostic criteria for their diagnosis and uses role-playing techniques to embody a client with that diagnosis and self-present themselves to the group who then has an opportunity to practice their assessment 
and diagnosis skills. Through this role-playing process, participants would have an opportunity to embody and experientially assess symptoms of various mental health diagnoses rather than simply read about or talk about differential diagnosis.

Sociodrama can also be employed as an educational tool to help explore professional issues or social issues in a spontaneous forum. A depiction of this comes from this author's psychodrama MSW course. Mid-way through the semester, students were asked to articulate some of their specific fears related to group facilitation. Responses included "not knowing what to say to a client," "having to stop group members who are arguing with each other," "being told I am too young or inexperienced," "accidentally saying something offensive," "not being able to contain someone's emotions," and "group members being unsatisfied with me as a group leader." These responses were written down, then put into action in a playful and spontaneous manner with the class so they could practice responding to each situation in the here-and-now. The class spontaneously transitioned into a clinical group with each student taking on a fictitious client role within the group therapy session. The director instructed the role players on the issues to enact while strategically role reversing students into the group leader role to practice responding to the difficult group experiences. With each difficult scenario, multiple students were role reversed into the group leader role to demonstrated different strategies of responding. In this way, students had a chance to practice responding to feared moments as group facilitators while learning from each other in a playful and safe context. A similar sociodramatic process is described by Khouri, Sampaio, and Albuquerque (2014) in their work with organizational leaders using sociodrama to enact feared situations and developing leadership competencies.

In a social work education or a supervision group that has already established cohesion, connection, safety, and an atmosphere of personal disclosure, issues of countertransference can be explored using role-playing. This process is formalized through the Therapeutic Spiral Model's advanced clinical training module on transference and countertransference. In this process, a clinician engages in a role-play to re-enact a difficult moment with a client where their own countertransference has been activated. The facilitator then instructs the clinician to identify who it is that they are have projected upon their client and to choose someone in the group to play the role of that person from the therapist's own life. Often, it is a parent, friend, partner, child, or former client of the therapist. Once this person has been identified and enrolled, a psychodrama ensues focusing on working out the therapist's unresolved personal issues with the person they are projecting upon their client. Once the scene moves to closure and resolution, the client-therapist relationship is revisited to integrate a new experience of being fully present with the client without the influence of countertransference. In this process, it is also common to explore the client's transference with the therapist and to consider who the client may be projecting upon the therapist. This knowledge offers the therapist greater objectivity and insight into how they can better serve their client in the future and work through both transference and countertransference issues in future sessions.

A final use of role-playing in social work supervision and education is the use of strengths-based psychodrama to help emerging social workers affirm their strengths 
and future social work goals. This can be done in a group setting with auxiliaries or in individual supervision settings using empty chairs or objects to represent roles. Many social work or psychodrama students express feeling inadequate, fearful, uncertain, or under-appreciated at their field placement sites. These feelings are frequently expressed during supervision sessions or during class sessions. Using strengthsbased psychodramas, one can be reminded of their inner strengths and interpersonal supports as it relates to their field placement experience. This writer has also found strengths-based psychodrama vignettes helpful for social work interns who express anxieties or insecurities related to facilitating groups. Below is a short excerpt from an individual supervision session where Cindy, the intern, expressed wanting to feel more confident facilitating a group for her first time:

INTERN:

SUPERVISOR:

INTERN:

SUPERVISOR:

INTERN:

SUPERVISOR:

INTERN AS CONFIDENCE: I am your confidence Cindy. You can connect with me more and remember the things we have accomplished together in the past. I am growing with each day in your internship. You don't have the run the best group ever, it just has to be good enough. And it is okay if you make mistakes. You are a student intern and the purpose of your internship is to practice, grow, and learn.

SUPERVISOR:

INTERN AS CONFIDENCE: Cindy, remember to breathe. When you feel insecure, you can take a deep breathe, straighten up your stance, and feel me in your body. If that doesn't help you discern how to respond, then you can simply be authentic with the group and say that you don't know what to do or say. Trust that the group knows what they need. You don't have all the answers, so don't pretend that you do-all you need to do is help the group find their own answers.

SUPERVISOR:
Right! Well said confidence. Go ahead and role reverse back. Cindy, take a moment to take in 
INTERN:

SUPERVISOR:

INTERN:

SUPERVISOR: and integrate those messages from your confidence (pointing to the small, framed painting concretizing confidence).

(quietly takes a few deep breathes while looking at the painting, then closes her eyes and shifts into a more confident posture).

Is this a good place to end?

Yeah, I feel much more confident-and much more relaxed at the same time. I think I was feeling like I had to be an expert, but this helped me remember my role as a facilitator helping the group find their own answers.

Here, why don't you take this with you and put it in the group room where it can remind you of your confidence (hands Cindy the small, framed painting).

This psychodrama vignette with Cindy was no more than ten minutes but helped to shift both her perception and her emotional experience related to facilitating her first group as an intern. The concretization of her confidence allowed her to integrate the psychodramatic learning into her experience as a group facilitator and throughout her internship as she was reminded of it each time she entered the supervisor's office and saw the small framed quote. Short strengths-based psychodrama vignettes like this can help support interns and students to tap into their strengths prior to facilitating groups, giving presentations, or even taking their license exams. A similar role reversal process is presented in a case study by Daniel (2016) resulting in a measured decrease in supervisee anxiety and an increase in supervisee confidence, spontaneity, and consciousness. Furthermore, Kayir (2012) offers a chapter devoted to using supervision to help psychodrama supervisees work through their anxiety of facilitation.

Through the use of role-playing techniques, including psychodrama, sociodrama, and other scripted role-plays, social work supervisors and educators can support students and supervisees as they emerge into professional social workers. Roleplaying offers opportunities for strengths-based intrapsychic growth and interpersonal role training of clinical skills within both individual or group settings. The integration of simple psychodrama philosophy, theory, and interventions can enhance the effectiveness of role-play within social work classrooms and supervisory contexts.

\subsection{Conclusion}

Social work education and supervision sessions, when infused with sociometry and role-playing techniques, offer engaging and embodied learning experiences for emerging social workers. Moreno's methods, in the hands of social work educators 
and supervisors, provide experiential teaching processes that cultivate mutual aid, spontaneity, and creativity. These processes are inherently strengths-based and can be used in trauma-informed ways to promote social justice and optimal social learning environments in individual or group contexts. Moreno's methods can be employed in social work classrooms, organizations, and private practice contexts to promote professional development and personal growth. Through sociometry, psychodrama, and sociodrama, next generation of social workers can be role trained to play the role of social worker with competence, self-reflection, and excellence.

\section{References}

Apter, N. (2012). Humanistic processing: The supervisor's role through reverse enactment. In H. Krall, J. Fürst, \& P. Fontaine (Eds.), Supervision in psychodrama (pp. 19-36). Wiesbaden: Springer.

Arthur, N., \& Achenbach, K. (2002). Developing multicultural counseling competencies through experiential learning. Counselor Education and Supervision, 42(1), 2-14.

Baile, W. F., \& Blatner, A. (2014). Teaching communication skills: Using action methods to enhance role-play in problem-based learning. Simulation in Health Care, 9(4), 220-227.

Banach, M., Foden, E. \& Carter, V. B. (2018). Educating undergraduate group workers: Increasing confidence through experiential learning. Social Work with Groups.

Bernard, J. (1979). Supervisor training: A discrimination model. Counselor Education and Supervision, 19, 60-68.

Bidart-Novaes, M., Brunstein, J., Gil, A. C., \& Drummond, J. (2014). Sociodrama as a creative learning strategy in business administration. Creative Education, 5, 1322-1333.

Blatner, A. (2006). Enacting the new academy: Sociodrama as a powerful tool in higher education. Revision: A Journal of Consciousness \& Transformation, 29, 30-35.

Blatner, A., \& Blatner, A. (1997). The art of play: Helping adults reclaim imagination and spontaneity (rev ed.). New York: Bruner/Mazel.

Bogo, M., Rawlings, M., Katz, E., \& Logie, C. (2014). Using simulation in assessment and teaching: OSCE adapted for social work. Alexandria, VA: Council on Social Work Education.

Brooks, S. L. (2006). Creative arts therapies manual: A guide to the history, theoretical approaches, assessment, and work with special populations of art, play, dance, music, drama, and poetry therapies (1st ed.). Springfield, IL: Charles C. Thomas Publisher Ltd.

Buchanan, D. R., \& Swink, D. F. (2017). Golden age of psychodrama at Saint Elizabeths hospital (1939-2004). Journal of Psychodrama, Sociometry, and Group Psychotherapy, 65(1), 9-32.

Bureau of Labor Statistics. (2018). Social workers. In Occupational outlook handbook. Retrieved from https://www.bls.gov/ooh/community-and-social-service/social-workers.htm.

Carey, L. A. (2016). Group work education: A call for renewed commitment. Social Work with Groups, 39(1), 48-61.

Center for Substance Abuse Treatment. (2009). Clinical supervision and professional development of the substance abuse counselor. Rockville, MD: U.S. Department of Health and Human Services.

Chesner, A. (2008). Psychodrama: A passion for action and non-action in supervision. In R. Shohet (Ed.), Passionate supervision (pp. 132-149). London: Jessica Kingsley Publishers.

Cheung, M., Alzate, K., \& Nguyen, P. V. (2012). Psychodrama preparation for internship. Field Educator: Practice Digest, 2(2), 1-13.

Cole, D. K. (2001). Psychodrama and the training of trial lawyers: Finding the story. Northern Illinois University Law Review, 21(1), 1-35. 
Cozolino, L. J. (2014). Attachment-based teaching: creating a tribal classroom. New York: W.W. Norton \& Company.

Dalton, B., \& Kuhn, A. C. (1998). Researching teaching methodologies in the classroom. Journal of Teaching in Social Work, 17(1/2), 169-184.

Daniel, S. (2012). The supervisory relationship in psychodrama training: More than a process. In H. Krall, J. Fürst, \& P. Fontaine (Eds.), Supervision in psychodrama (pp. 111-128). Wiesbaden: Springer.

Daniel, S. (2016). The usefulness of role reversal in one-to-one supervision: a qualitative research project using heuristic enquiry. In Psychodrama. Empirical research and science (Vol. 2, pp. 235253). Wiesbaden: Springer.

Dennison, S. (2005). Enhancing the integration of group theory with practice: A five-part teaching strategy. Journal of Baccalaureate Social Work, 10(2), 53-68.

Dewey, J. (1916). Democracy and education: An introduction to the philosophy of education. New York: The Free Press.

Drakulić, A. M. (2014). Critical reflections for understanding the complexity of psychodramatic theory. Psychiatria Danubina, 26(1), 12-19.

Dudler, A., \& Weiß, K. (2012). Interlocking gear wheels-From training to practice in various professional fields. In H. Krall, J. Fürst, \& P. Fontaine (Eds.), Supervision in psychodrama (pp. 5772). Wiesbaden: Springer.

Ebersole, G., Leiderman, P., \& Yalom, I. (1969). Training the nonprofessional group therapist. Journal of Nervous and Mental Disorders, 149, 294-302.

Euster, G. L. (1979). Trends in education for social work practice with groups. Journal of Education for Social Work, 15, 94-99.

Evans, K. M. (1962). Sociometry and education. London: Routledge and Kegan Paul.

Ferrándiz-Vindel, I. M., \& Jimenez, B. C. (2011). The sociogram: The analysis of interpersonal relationships in higher education. Journal of International Education Research (JIER), 7(5), 9-14.

Fleischer, L. (2018). "Her anger frightens me!” using group-work practice principles and feature films in teaching clinical practice in mental health. Social Work with Groups, 41(3), 244-258.

Foels, L. E., \& Bethel, J. C. (2018). Revitalizing social work education using the arts. Social Work with Groups, 41(1-2), 74-88.

Fox, R. (2013). The call to teach: Philosophy, process, and pragmatics of social work education. Alexandria, VA: Council on Social Work Education.

Freire, P. (2013). Education for critical consciousness. London: Bloomsbury.

Furman, R., Rowan, D., \& Bender, K. (2009). An experiential approach to group work. Chicago, IL: Lyceum Books.

Georgiou, I., Zahn, C., \& Meira, B. (2008). A systematic framework for case-based classroom experiential learning. Systems Research and Behavioral Science, 25(6), 807-819.

Gershoni, J. (2009). Bringing psychodrama to the main stage in group psychotherapy. Group, 33(4), 297-308.

Giacomucci, S. (2017). The sociodrama of life or death: Young adults and addiction treatment. Journal of Psychodrama, Sociometry, and Group Psychotherapy, 65(1), 137-143. https://doi. org/10.12926/0731-1273-65.1.137.

Giacomucci, S. (2018). Social work and sociometry: Integrating history, theory, and practice. The clinical voice. Richboro, PA: Pennsylvania Society for Clinical Social Work.

Giacomucci, S. (2019a). Moreno's methods in academia (or the lack of): A call to action. In Psychodrama network news (p. 20). American Society of Group Psychotherapy and Psychodrama, Fall 2019.

Giacomucci, S. (2019b). Social group work in action: A sociometry, psychodrama, and experiential trauma therapy curriculum (Doctorate in Social Work (DSW) Dissertations. 124. ProQuest Dissertations and Theses). https://repository.upenn.edu/cgi/viewcontent.cgi?article $=1128 \&$ con text=edissertations_sp2. 
Giacomucci, S. (2020a). Addiction, traumatic loss, and guilt: A case study resolving grief through psychodrama and sociometric connections. The Arts in Psychotherapy, 67, 101627. https://doi. org/10.1016/j.aip.2019.101627.

Giacomucci, S. (2020b). Best practices for psychodrama in academia: The role transition from trainer to professor. American Society of Group Psychotherapy \& Psychodrama Professional Liaison Committee. Retrieved from https://asgpp.org/wp-content/uploads/2020/08/Best-Practi ces-Psychodrama-in-Academia.pdf.

Giacomucci, S. (2020c). Experiential sociometry in group work: Mutual aid for the group-asa-whole. Social Work with Groups, Advanced Online Publication. https://doi.org/10.1080/016 09513.2020.1747726.

Giacomucci, S., Gera, S., Briggs, D., \& Bass, K. (2018). Experiential addiction treatment: Creating positive connection through sociometry and therapeutic spiral model safety structures. Journal of Addiction and Addictive Disorders, 5, 17. https://doi.org/10.24966/AAD-7276/100017.

Giacomucci, S., \& Skolnik, S. (in-press). The experiential social work educator: Integrating sociometry into the classroom environment. Journal of Teaching Social Work.

Gimenez Hinkle, M. (2008). Psychodrama: A creative approach for addressing parallel process in group supervision. Journal of Creativity in Mental Health, 3(4), 401-415.

Gitterman, A. (2004). Interactive andragogy: Principles, methods, and skills. Journal of Teaching in Social Work, 24(3/4), 95-112.

Gomes, A. M. A., Albuquerque, C. M., Moura, E. R. F., \& Vieira, L. J. E. S. (2006). Aplicação do psicodrama pedagógico na compreensão do Sistema Único de Saúde: Relato de experiência. Psicologia para America Latina, 6.

Goodman, H., \& Munoz, M. (2004). Developing social group work skills for contemporary agency practice. Social Work with Groups, 27(1), 17-33.

Guldner, C. A., \& Stone-Winestock, P. (1995). The use of sociometry in teaching at the university level. Journal of Group Psychotherapy, Psychodrama, and Sociometry, 47(4), 177-186.

Gutman, C., \& Shennar-Golan, V. (2012). Instilling the soul of group work in social work education. Social Work with Groups, 35(2), 138-149.

Haas, R. B. (1949). Psychodrama and sociodrama in American education. Beacon, NY: Beacon Press.

Hawkins, P., \& Shohet, R. (2012). Supervision in the helping professions (4th ed.). United Kingdom: McGraw-Hill Education.

Haworth, P., \& Vasiljevic, L. (2012). Psychodrama and action methods in education. Andragoške Studije, 1, 113-127.

Ieva, K. P., Ohrt, J. H., Swank, J. M., \& Young, T. (2009). The impact of experiential groups on master students' counselor and personal development: A qualitative investigation. The Journal for Specialists in Group Work, 34(4), 351-368.

Jacobs, A. J. (1950). Sociodrama and teacher education. Journal of Teacher Education, 1(3), 192198.

Jennings, H. H. (1948). Sociometry in group relations: A work guide for teachers. Washington, DC: American Council on Education.

Johnson, D. R., \& Emunah, R. (2009). Current approaches in drama therapy (2nd ed.). Springfield, IL: Charles C. Thomas Publisher.

Jones, M. (1968). Beyond the therapeutic community. New Haven, CT: Yale University Press.

Kadushin, A., \& Harkness, D. (2014). Supervision in social work. New York: Columbia University Press.

Kaye, L., \& Fortune, A. (2001). Coping skills and learning in social work field education. The Clinical Supervisor, 20(2), 31-42.

Kayır, A. (2012). Trainee's anxiety to direct: Supervision as a journey from anxiety to curiosity. In H. Krall, J. Fürst, \& P. Fontaine (Eds.), Supervision in psychodrama (pp. 151-160). Wiesbaden: Springer.

Keeton, M. T., \& Tate, P. J. (Eds.). (1978). Learning by experience-What, why, how: New directions for experiential learning. San Francisco: Jossey-Bass Publishing. 
Kellermann, P. F. (1992). Focus on psychodrama: The therapeutic aspects of psychodrama. London, UK: Jessica Kingsley.

Khouri, G. S., Sampaio, M., \& Albuquerque, C. F. L. D. (2014). Dialogue with the leadership through the sociodrama: From feared scenes to the development of competencies. Revista Brasileira de Psicodrama, 22(1), 22-31.

Knight, C. (2017) Social work students' experiences with group work in the field practicum. Journal of Teaching in Social Work, 37(2), 138-155.

Kolb, D. A. (1984). Experiential learning: Experience as the source of learning and development. Englewood Cliffs, NJ: Prentice Hall.

Kolk, D. A. (2014). Experiential learning: Experience as the source of learning and development (2nd ed.). New Jersey: Pearson Education Inc.

Kolb, D. A., \& Kolb, A. Y. (2005). Learning styles and learning spaces: Enhancing experiential learning in higher education. Academy of Management Learning \& Education, 4(2), 193-212.

Kolb, D. A., \& Kolb, A. Y. (2017). The experiential educator: Principles and practices of experiential learning. Kaunakakai, HI: Experienced Based Learning Systems Press.

Konopik, D. A., \& Cheung, M. (2013). Psychodrama as a social work modality. Journal of Social Work, 58(1), 9-20.

Koob, J., \& Funk, J. (2002). Kolb's learning style inventory: Issues of validity and reliability. Research on Social Work Practice, 12(2), 293-308.

Krall, H. (2012). Training and research in supervision-An introduction. In H. Krall, J. Fürst, \& P. Fontaine (Eds.), Supervision in psychodrama (pp. 201-206). Wiesbaden: Springer.

Krall, H., \& Fürst, J. (2012). Supervision and evaluation: Objectives, practices and helpful aspects. In H. Krall, J. Fürst, \& P. Fontaine (Eds.), Supervision in psychodrama (pp. 259-278). Wiesbaden: Springer.

Krall, H., Fürst, J., \& Fontaine, P. (2012). Supervision in psychodrama-an introduction. In H. Krall, J. Fürst, \& P. Fontaine (Eds.), Supervision in psychodrama (pp. 9-12). Wiesbaden: Springer.

Kramer, B. J., \& Wrenn, R. (1994). The blending of andragogical and pedagogical teaching methods in advanced social work practice courses. Journal of Teaching in Social Work, 10(1/2), 43-64.

Landis, H. (2020). Collective stories: The application of sociodrama with high school immigrant students. Social work with groups. Advanced Online Publication. https://doi.org/10.1080/016 09513.2020.1811014.

Landy, R. J. (2017). The love and marriage of psychodrama and drama therapy. The Journal of Psychodrama, Sociometry, and Group Psychotherapy, 65(1), 33-40.

LaRocque, S. E. (2017). Group work education in social work: A review of the literature reveals possible solutions. Journal of Social Work Education, 53(2), 276-285.

Liberali, R., \& Grosseman, S. (2015). Uso de Psicodrama em medicina no Brasil: Uma revisão de literatura. Interface (Botucatu), 19(54), 561-571.

Lu, Y. E., Ain, E., Chamorro, C., Chang, C., Feng, J. Y., Fong, R., \& Yu, M. (2011).A new methodology for assessing social work practice: The adaptation of the objective structured clinical evaluation (SW-OSCE). Social Work Education, 30, 170-185.

MacGowan, M., \& Vakharia, S. (2012). Teaching standards-based group work competencies to social work students: An empirical examination. Research on Social Work Practice, 22(4), 380388.

Marineau, R. (2014). Jacob Levy Moreno 1889-1974: Father of psychodrama, sociometry, and group psychotherapy. Princeton, New Jersey: Psychodrama Press.

Maya, J., \& Maraver, J. (2020). Teaching-learning processes: Application of educational psychodrama in the University setting. International Journal of Environmental Research and Public Health, 17(11), 3922.

McCarthy, M. (2010). Experiential learning theory: From theory to practice. Journal of Business \& Economics Research, 8(5), 131-139.

McGovern, M., \& Harmsworth, P. (2010). A taste of reflecting practice. Journal of Family Therapy, 32(4), 440-443. 
McKinney, J., O'Conner, V., \& Pruitt, D. (2018). Experiential learning through group work and theater. Social Work with Groups, 41(1-2), 49-59.

McLaughlin, D. E., Freed, P. E., \& Tadych, R. A. (2006). Action methods in the classroom: Creative strategies for nursing education. International Journal of Nursing Education Scholarship, 3(1).

Michaels, T. J., \& Hatcher, N. C. (1972). Sociodrama in the classroom: A different approach to learning. The High School Journal, 55(4), 151-156.

Mooradian, J. K. (2007). Simulated family therapy interviews in clinical social work education. Journal of Teaching in Social Work, 27(1/2), 89-104.

Mooradian, J. K. (2008). Using simulated sessions to enhance clinical social work education. Journal of Social Work Education, 44(3), 21-35.

Mor Barak, M. E., Travis, D. J., Pyun, H., \& Xie, B. (2009). The impact of supervision on worker outcomes: A meta-analysis. Social Service Review, 83(1), 3-32.

Moreno, J. L. (1946). Psychodrama (Vol. 1). Beacon, NY: Beacon House Press.

Moreno, J. L. (1949). The spontaneity theory of learning. In R. B. Hass (Ed.), Psychodrama and sociodrama in American education. Beacon, NY: Beacon House Press.

Moreno, J. L. (1953). Who shall survive? Foundations of sociometry, group psychotherapy and sociodrama (2nd ed.). Beacon, NY: Beacon House.

Moreno, J. L. (1955). Preludes to my autobiography. Beacon, NY: Beacon House.

Moreno, J. L. (2011). The Autobiography of J. L. Moreno (abridged). United Kingdom: North-West Psychodrama Association.

Moreno, J. L. (2012a). Preludes to my autobiography (reprint of 1955 ed.). United Kingdom: North-West Psychodrama Association.

Moreno, J. L., \& Moreno, Z. T. (1959). Foundations of psychodrama (Vol. II). Beacon, NY: Beacon House Press.

Moreno, Z. T. (2012b). A message from Zerka. Psychodrama network news (p. 5). American Society of Group Psychotherapy and Psychodrama, Fall 2012.

Munson, C. (2012). Handbook of clinical social work supervision. Birmingham, NY: Routledge.

Nery, M. D. P., \& Gisler, J. V. T. (2019). Sociodrama: An active method in research, teaching and educational intervention. Revista Brasileira de Psicodrama, 27(1), 11-19.

Nicholas, M. W. (2017). The use of psychodrama and sociometry techniques in psychodynamic and other process groups. International Journal of Group Psychotherapy, 67(S1), S131-S140.

Nolte J. (2018) Psychodrama and creativity in education. In: Burgoyne, S. (Eds.), Creativity in theatre. Creativity theory and action in education (Vol. 2). Cham, Switzerland: Springer Publishing.

Ochs, P. (2020). Using action methods in clinical supervision: A journey from talk to action. Social Work with Groups, Advanced Online Publication. https://doi.org/10.1080/01609513.2020.179 3057.

Ochs, P., \& Webster, J. (2017). Family therapy supervision in action. The Journal of Psychodrama, Sociometry, and Group Psychotherapy, 65(1), 111-121.

Oudijk, R. (2007). A postmodern approach to psychodrama theory. In C. Baim, Clark, J. Burmeister, \& M. Maciel, Manuela (Eds.), Psychodrama: Advances in theory and practice (pp. 139-150). New York: Routledge, Taylor \& Francis Group.

Powell, J. Y., \& Causby, V. D. (1994). From the classroom to the capitol-from MSW students to advocates: Learning by doing. Journal of Teaching in Social Work, 9(1/2), 141-154.

Propper, H. (2003). Psychodrama as experiential education: exploring literature and enhancing a cooperative learning environment. In J. Gershoni (Ed.), Psychodrama in the 21st century: clinical and educational applications (pp. 229-248). New York: Springer Publishing Company.

Pugh, G. L. (2014). Revisiting the pink triangle exercise: An exploration of experiential learning in graduate social work education. Journal of Teaching in Social Work, 34(1), 17-28.

Quinn, P., Jacobsen, M., \& LaBarber, L. (1992). Utilization of group projects in teaching social work research methods: Benefits to students and faculty. Journal of Teaching in Social Work, 6(1), 63-76. 
Ramsauer, S. (2007). Psychodramatische Supervision in der Sozialen Arbeit: Kleine Interventionen mit großer Wirkung. Zeitschrift für Psychodrama und Soziometrie, 6(2), 293-302.

Raschick, M., Maypole, D., \& Day, P. (1998). Improving field education through Kolb learning theory. Journal of Social Work Education, 34(1), 31-42.

Rawlings, M. A. (2012). Assessing BSW student direct practice skill using standardized clients and self-efficacy theory. Journal of Social Work Education, 48, 553-576.

Rogers, C. (1961). On becoming a person: A therapist's view of psychotherapy. Boston, MA: Houghton Mifflin.

Sachdev, P. (1997). Cultural sensitivity training through experiential learning: A participatory demonstration field education project. International Social Work, 40(1), 7-25.

Schön, D. (1987). Educating the reflective practitioner: Toward a new design for teaching and learning in the professions. San Francisco, CA: Jossey-Bass.

Schreiber, J. C., \& Minarik, J. D. (2018). Simulated clients in a group practice course: Engaging facilitation and embodying diversity. Journal of Social Work Education, 54(2), 310-323.

Semb, G. B., \& Ellis, J. A. (1994). Knowledge taught in school: What is remembered? Review of Educational Research, 64(2), 253-286.

Shera, W., Muskat, B., Delay, D., Quinn, A., \& Tufford, L. (2013). Using a group work practice standards inventory to assess the impact of a "social work practice with groups" course. Social Work with Groups, 36(2-3), 174-190.

Shulman, L. (1987). The hidden group in the classroom. Journal of Teaching in Social Work, 1(2), 3-31.

Shulman, L. (2010a). Dynamics and skills of group counseling. Belmont, CA: Cengage Learning.

Shulman, L. (2010b). Interactional supervision (3rd ed.). Washington, DC: NASW Press.

Siegel, D. J. (2012). Developing mind: How relationships and the brain interact to shape who we are. New York: Guilford Press.

Sobieski, C., \& Dell' Angelo, T. (2016). Sociograms as a tool for teaching and learning: Discoveries from a teacher research study. The Educational Forum, 80(4), 417-429.

Specht, L. B., \& Sandlin, P. K. (1991). The differential effects of experiential learning activities and traditional lecture classes. Simulation \& Gaming, 22(2), 196-210.

Sternberg, P., \& Garcia, A. (2000). Sociodrama: Who's in your shoes? Westport, CT: Praeger Publishers.

Strozier, A. L. (1997). Group work in social work education: What is being taught? Social Work with Groups, 20(1), 65-77.

Swiller, H. I. (2011). Process groups. International Journal of Group Psychotherapy, 61(2), 263273.

Tabib, S. L. (2017). Effective psychodrama supervision a grounded theory study on senior supervisors' perspectives. Doctoral dissertation, Lesley University. Retrieved from https://digitalco mmons.lesley.edu/expressive_dissertations/4/.

ter Avest, I. (2017). "I experienced freedom within the frame of my own narrative": The contribution of psychodrama techniques to experiential learning in teacher training. International Review of Education, 63(1), 71-86.

Truedley, M. B. (1944). Psychodrama and social case work. Sociometry, 7, 170-178.

Tully, G. (2015). The faculty field liaison: An essential role for advancing graduate and undergraduate group work education. Social Work with Groups, 38(1), 6-20.

Veiga, S., Bertão, A., \& Franco, V. (2015). Sociodrama in the training of social educators: An exploratory research. The Journal of Psychodrama, Sociometry, and Group Psychotherapy, 63(1), 47-64.

Walters, R., \& Baile, W. F. (2014). Training oncology professionals in key communication skills: Adapting psychodrama and sociodrama for experiential learning. The Journal of Psychodrama, Sociometry, and Group Psychotherapy, 62(1), 55-66.

Warkentin, B. (2017) Teaching social work with groups: Integrating didactic, experiential and reflective learning. Social Work with Groups, 40(3), 233-243. 
Wehbi, S. (2011). Reflections on experiential teaching methods: Linking the classroom to practice. Journal of Teaching in Social Work, 31(5), 493-504.

Whiteman, V. L., \& Nielsen, M. (1990). Drama in teaching survey research methods: An experimental evaluation. Journal of Teaching in Social Work, 4(2), 67-81.

Wiener, R. (1988). Sociodrama and management training. Industrial and Commercial Training, 20(4), 18-20.

Williams, A. (1995). Visual and active supervision: Roles, focus, technique. New York: W. W. Norton.

Williams, A. J. (1988). Action methods in supervision. The Clinical Supervisor, 6(2), 13-27.

Yalom, I. D., \& Leszcz, M. (2005). The theory and practice of group psychotherapy (5th ed.). New York, NY: Basic Books.

Zastrow, C. (2001). Social work with groups: using the classroom as a group leadership laboratory (5th ed.). Pacific Grove, CA: Brooks/Cole.

Open Access This chapter is licensed under the terms of the Creative Commons Attribution 4.0 International License (http://creativecommons.org/licenses/by/4.0/), which permits use, sharing, adaptation, distribution and reproduction in any medium or format, as long as you give appropriate credit to the original author(s) and the source, provide a link to the Creative Commons license and indicate if changes were made.

The images or other third party material in this chapter are included in the chapter's Creative Commons license, unless indicated otherwise in a credit line to the material. If material is not included in the chapter's Creative Commons license and your intended use is not permitted by statutory regulation or exceeds the permitted use, you will need to obtain permission directly from the copyright holder. 